\title{
GASTROPROTECTIVE ACTIVITY OF EQUISETUM HYEMALE IN EXPERIMENTAL GASTRIC ULCER RAT MODELS
}

\author{
NAGHMANA ${ }^{1}$, MUHAMMAD NAVEED MUSHTAQ ${ }^{1}$, KASHIF BARKAT $^{2}$, FARAH ABID $^{1}$, \\ IRFAN ANJUM ${ }^{1 *}$
}

${ }^{I}$ Department of Pharmacology, Faculty of Pharmacy, The University of Lahore, Pakistan

${ }^{2}$ Department of Pharmaceutics, Faculty of Pharmacy, The University of Lahore, Pakistan

*corresponding author: anjuum95@yahoo.com

Manuscript received: March 2020

\begin{abstract}
Equisetum hyemale is traditionally used for dyspepsia and stomach pain. The aim of the present study was to evaluate the gastroprotective activity of the aqueous ethanolic extract of the aerial parts of Equisetum hyemale in gastric ulcer rat models. Gastric ulcer models were induced by ethanol ( $5 \mathrm{~mL} / \mathrm{kg} \mathrm{bw})$, acetylsalicylic acid (ASA) $(200 \mathrm{mg} / \mathrm{kg} \mathrm{bw}$ ) and pylorus ligation separately. The $\mathrm{pH}$, total acidity, ulcer scoring index and histopathological evaluation were performed. Oral administration of Equisetum hyemale extract $(250$ and $500 \mathrm{mg} / \mathrm{kg} \mathrm{bw}$ ) significantly reduced the development of gastric lesions in all gastric ulcer models. The $\mathrm{pH}$, total acidity and ulcer scoring index also decreased significantly when compared with the Diseased control group. Histopathological studies are in good agreement with the biochemical findings. Equisetum hyemale might show its gastroprotective activity by decreasing oxidative damage, blockage of $\mathrm{H}_{2}$ receptors activation, increase prostaglandins secretion and formation of mucus layer in different gastric ulcer models. The findings of the present study validate the traditional use of Equisetum hyemale to treat stomach pain, however the determination of phytochemical compounds responsible for gastroprotective activity is required for further confirmation.
\end{abstract}

\section{Rezumat}

Equisetum hyemale este utilizată în mod tradițional în tratamentul patologiei digestive. Scopul studiului a fost evaluarea activității gastroprotectoare a extractului etanolic apos obținut din pățile aeriene ale Equisetum hyemale la modele de şobolani cu ulcer gastric. Modelele de ulcer gastric au fost induse cu etanol ( $5 \mathrm{~mL} / \mathrm{kg}$ corp), acid acetilsalicilic $(200 \mathrm{mg} / \mathrm{kg}$ corp) și ligarea pilorului. S-au determinat pH-ul, aciditatea totală, indexul de ulcer gastric şi evaluarea histopatologică. Administrarea orală a extractului de Equisetum hyemale (250 și $500 \mathrm{mg} / \mathrm{kg}$ corp) a redus semnificativ dezvoltarea leziunilor gastrice în toate modelele experimentale. pH-ul, aciditatea totală și indicele de ulcer au scăzut, de asemenea, semnificativ în comparație cu grupul control. Studiile histopatologice sunt în concordanță cu rezultatele biochimice. Equisetum hyemale prezintă activitate gastroprotectoare prin scăderea leziunilor oxidative, blocarea activării receptorilor H2, creșterea secreției de prostaglandine şi formarea stratului de mucus. Rezultatele prezentului studiu validează utilizarea tradițională a Equisetum hyemale pentru tratarea afecțiunilor gastrice. Determinarea compușilor fitochimici responsabili de activitatea gastroprotectoare este necesară pentru confirmarea efectului terapeutic.

Keywords: gastroprotective, ethanol, acetylsalicylic acid, pylorus ligation, ulcer

\section{Introduction}

Peptic ulcer is a disease of gastrointestinal tract affecting approximately $10 \%$ of the world population [1]. Disturbance in the balance between defensive and offensive factors leads to the development of peptic ulcer [2]. High acid secretion, use of alcohol, nonsteroidal anti-inflammatory drugs and Helicobacter pylori infection are between the offensive factors [3]. Peroxidation of lipids and reactive oxygen species are also involved in the pathophysiology of peptic ulcer [4]. However, medicinal treatment of peptic ulcer may fail due to adverse reactions such as development of hypersensitivity, gynecomastia, impotence, arrhythmia and hematopoietic changes by antacids, $\mathrm{H}_{2}$-receptor antagonists and proton pump inhibitors [5, 6].
In recent years, due to the prevalence of peptic ulcer disease and side effects of anti-ulcer drugs, interest in the use of natural products as sources of new drugs for treating peptic ulcer has been increased [7]. Equisetum hyemale L. (E. hyemale) also known as horsetail, belongs to the Equisetaceae family. E. hyemale is deep green, straight, unbranched herb and consists of hollow stem with reduced leaves at nodes. The cone is sharply pointed, about $7-15 \mathrm{~mm}$ long and partly concealed by the teeth of the uppermost sheath. The habitat of the plant is represented by wet places, ponds, marshes, wet woodland and the banks of lakes and rivers [8]. It is traditionally used for wounds, asthma, renal stones, kidney disease, acute stroke, high blood pressure, bleeding, cancer, conjunctivitis, rheumatoid arthritis, pyelonephritis, 
stomach pain and also has anti-proliferative effects [9]. Solution of stem is also used to wash sores on children's skin [10]. The main phytochemicals reported after screening are phenols, (ferulic acid isomers, feruloyl and caffeoyl glucosides) flavonoids, flavonol glucosides and alkaloids. The high silica contents of the plant suggested the efficacy of the plant in rheumatoid arthritis and osteoporosis [11]. In addition, the plant is rich in minerals, bioflavonoids and phenols that potentiate the antioxidant activity which may explain its role in bone healing. The main mineral elements identified in the dried powder of $E$. hyemale aerial part are iron, silica, zinc, manganese, copper and chromium [12]. E. hyemale has been used in stomach diseases traditionally, but it has not been proved yet. The aim of the present study was to investigate the gastroprotective activity of aqueous ethanolic extract of the aerial parts of $E$. hyemale in ulcer induced animal models. For this purpose, different animal models including ethanol-induced gastric ulcer, acetylsalicylic acid (ASA) induced ulcer and pylorus ligation-induced ulcer models have been used. Macroscopic evaluation, $\mathrm{pH}$, total acidity and ulcer index of stomach were calculated in order to evaluate the gastroprotection of E. hyemale. In this study, three animal models were used to find out the mechanism of gastroprotective activity of E. hyemale. Furthermore, histopathology studies were also performed.

\section{Materials and Methods}

\section{Plant collection}

Aerial parts of $E$. hyemale L. were harvested from the river Swat sides Tehsil Adenzai Chakdara District Lower Deer, Pakistan. The plant material was dried and grinded into powder. Identification of the voucher specimens was performed by Prof. Dr. Zaheer-udDin (Department of Botany, GC University Lahore, Pakistan) and voucher GC.Herb.Bot.3527 was issued. Animals

Wistar rats of either gender (200 - $250 \mathrm{~g}$ ) were used. The animals were kept in controlled laboratory environments (by monitoring temperature, humidity and light/dark cycle). Animals were kept seven days, for adaptation prior to any investigational techniques and they were fed with standard food and water.

Chemicals and reagents

Ethanol of analytical grade (Sigma Aldrich) was used to obtain the plant extract. All the chemicals used like buffered formalin, sodium hydroxide, phenolphthalein, tween 80, carboxy methyl cellulose, sucralfate and acetylsalicylic acid were of analytical grade (Sigma Aldrich).

\section{Preparation of plant extract}

The plant extract was prepared by soaking the dried, grinded aerial parts of $E$. hyemale $(988 \mathrm{~g}$ ) in aqueous ethanol $(3000 \mathrm{~mL})$ in a manner that a layer of solvent was maintained on the top, with occasional shaking for 72 hours. After three days, filtration of extract was carried out with cotton cloth and the plant material was again subjected to be soaked in further aqueous ethanol $(1500 \mathrm{~mL})$ for three further days. Finally, the second part of the extract was filtered and the parts were mixed. The obtained extract was further concentrated using a rotary evaporator for 12 hours at a temperature not more than $40^{\circ} \mathrm{C}$ at a speed of $60 \mathrm{rpm}$ under a pressure of $0.09 \mathrm{MPa}$. The concentrated extract was placed in an oven at a temperature of $40^{\circ} \mathrm{C}$ in order to obtain a semisolid form. The yield was $7.8 \%$. Study design

The current protocols were approved by the Committee of Animal Care and Use of Faculty of Pharmacy, University of Lahore, Pakistan. Three rat ulcer models have been induced: ethanol-induced gastric ulcer; ASA-induced gastric ulcer; pyloric-ligation induced gastric ulcer.

\section{Ethanol induced gastric ulcer}

The ulcer model has been induced by absolute ethanol $(5 \mathrm{~mL} / \mathrm{kg}$ bw/day) given by oral gavage. Twenty rats were randomly divided into five groups (four rats in each group). Group I (Control group): rats received vehicle - $1 \%$ tween $80(0.5 \mathrm{~mL} / \mathrm{kg} \mathrm{bw})$ by gavage for seven days. Group II (Diseased control group): received a single oral dose of absolute ethanol $(5 \mathrm{~mL} / \mathrm{kg}$ bw/day) for seven days. Group III (Standard drug treated group): received sucralfate $(100 \mathrm{mg} / \mathrm{kg}$ bw/day) and $5 \mathrm{~mL} / \mathrm{kg}$ bw/day ethanol one hour after administration of sucralfate for seven days. Group IV (E. hyemale extract $(250 \mathrm{mg} / \mathrm{kg} \mathrm{bw})$ treated group received an oral dose of E. hyemale extract ( $250 \mathrm{mg} / \mathrm{kg}$ bw/day) and ethanol ( $5 \mathrm{~mL} / \mathrm{kg}$ bw/day) one hour after the administration of plant extract for seven days. Group V (E. hyemale extract $500 \mathrm{mg} / \mathrm{kg} \mathrm{bw}$ ) treated group received a single oral dose of $500 \mathrm{mg} / \mathrm{kg}$ bw/day E. hyemale extract followed by administration of ethanol $(5 \mathrm{~mL} / \mathrm{kg} \mathrm{bw} /$ day) one hour after, by gavage, for seven days.

Animals were kept fasted after the dose of day 7 , for 24 hours and euthanized on the $8^{\text {th }}$ day and their stomachs were immediately dissected [13].

ASA induced gastric ulcer model

The study was performed with some modification as previously reported [14]. Twenty rats were randomly divided into five groups (four rats each group). Following, the rats were fasted for $36 \mathrm{~h}$, and they were treated as follows; Group I (Control group): received an oral dose of vehicle, $1 \% \mathrm{CMC}(1.7 \mathrm{~mL} / \mathrm{kg} \mathrm{bw})$. Group II (Diseased control group): received a single dose of ASA (200 mg/kg bw) by gavage. Group III (Standard drug treated group): received an oral dose of sucralfate $(100 \mathrm{mg} / \mathrm{kg}$ bw/day) and ASA (200 $\mathrm{mg} / \mathrm{kg} \mathrm{bw}$ ) 1 hour after administration of sucralfate by gavage. Group IV (E. hyemale extract $250 \mathrm{mg} / \mathrm{kg}$ bw) treated group received oral dose of $E$. hyemale extract $(250 \mathrm{mg} / \mathrm{kg} \mathrm{bw})$ and ASA (200 mg/kg bw) after one hour of the plant extract administration. Group V $(E$. 
hyemale extract $500 \mathrm{mg} / \mathrm{kg}$ bw/day) treated group received a single oral dose $(500 \mathrm{mg} / \mathrm{kg}$ bw) of $E$. hyemale extract followed by administration of ASA $(200 \mathrm{mg} / \mathrm{kg} \mathrm{bw})$ after one hour, by gavage. Four hours after the ASA dose, the animals were killed, dissected and their stomachs were isolated.

Pylorus ligation-induced gastric ulcer model Group I (Control group): the animals were given Tween 80 one hour before anaesthesia. The animals were anesthetized, dissected, but no ligation has been performed. Group II (Diseased control group): normal rats that were anesthetized and the pylorus was ligated for four hours. Group III (Standard drug treated group): orally received sucralfate $(100 \mathrm{mg} / \mathrm{kg} \mathrm{bw})$, one hour before anaesthesia and pylorus was ligated for four hours. Group IV (E. hyemale extract $250 \mathrm{mg} / \mathrm{kg}$ bw) treated group received a single oral dose of $E$. hyemale extract $250 \mathrm{mg} / \mathrm{kg}$ bw/day one hour before anaesthesia and pylorus was ligated for four hours. Group V (E. hyemale extract $500 \mathrm{mg} / \mathrm{kg}$ bw) treated group received orally a single dose of $E$. hyemale extract $500 \mathrm{mg} / \mathrm{kg}$ bw one hour before anaesthesia and pylorus was ligated for four hours.

The study was carried out in accordance to the defined procedures with modifications [15]. After the rats were fasted for $24 \mathrm{hr}$, ketamine/xylazine cocktail (ketamine $91 \mathrm{mg} / \mathrm{kg}$ bw and xylazine $9.1 \mathrm{mg} / \mathrm{kg}$ bw) were used to achieve surgical anaesthesia to make central abdominal cut to ligate the pylorus without any disruption of blood supply. The stomach was placed cautiously and the abdominal wall was stitched off with the help of sutures. The water intake was held during the post ligation period. The rats were euthanised, and the stomachs were isolated and cut open along the greater curvature to find out the ulcer index after four hours. For the histopathology study, stomach samples were collected and preserved in 10\% buffered formalin solution.

\section{Determination of $\mathrm{pH}$}

The stomachs were removed and the gastric content were drained out, collected and centrifuged at 2500 rpm for $10 \mathrm{~min}$ in order to remove solid particles. Then the $\mathrm{pH}$ of gastric juice was checked by using $\mathrm{pH}$ litmus paper [16].

\section{Total acidity determination}

One $\mathrm{mL}$ distilled water has been used to dilute $1 \mathrm{~mL}$ of gastric juice in a conical flask. Phenolphthalein has been uses as an indicator, and titrated against $0.01 \mathrm{~N} \mathrm{NaOH}$. Pink coloration indicated the end point [16]:

$$
\text { Acidity }=\frac{V_{N a O H} \times N \times 100 \mathrm{mEq} / \mathrm{L}}{0,1},
$$

where $\mathrm{V}_{\mathrm{NaOH}}$ is the volume of $0.01 \mathrm{~N} \mathrm{NaOH}$ and $\mathrm{N}$ is the normality of solution.

Macroscopic Examination

The stomach was washed with normal saline to remove gastric contents and blood clots. Stomachs were then dried, macroscopically evaluated by using a 10 $\mathrm{X}$ magnifier lens for gross gastric injury.

Determination of gastric ulcer index (UI) and percentage of inhibition

The ulcer index was calculated by adding the total number of ulcers per stomach, the total severity of ulcers per stomach and percentage of animals with ulcers and multiplying by 0.1 [17]. The severity of gastric ulcer score were: $0=$ no ulcers; $1=$ changes limited superficial layer of the mucosa with no congestion; $2=$ half the mucosal thickness showed necrotic changes; $3=$ more than $66 \%$ of the mucosal thickness showed necrotic changes; $4=$ complete destruction of the mucosa with haemorrhage.

The mean score was calculated and expressed as the UI. The percentage protection was calculated by using the following formula:

$$
\text { Protection }(\%)=\left(C-\frac{C}{T}\right) \times 100,
$$

where $\mathrm{C}=$ ulcer index in control group, $\mathrm{T}=$ ulcer index in treated groups [18].

Histopathologic examination and microscopic scoring of gastric damage

The samples were preserved in $10 \%$ buffered formalin and studied after staining by haematoxylin and eosin. Depending upon the severity of lesions, ulcers are scored as follows: $0=$ no ulcer, $1=$ superficial mucosal erosion, $2=$ deep ulcer or transmural necrosis, $3=$ perforated or penetrated ulcer [19].

Statistical Analysis

Data have been expressed as mean \pm standard error and statistically evaluated using one way ANOVA followed by Tuckey's multiple comparison test. $\mathrm{p}<$ 0.05 was considered as statistically significant.

\section{Results and Discussion}

\section{Ethanol-induced ulcer model \\ Determination of $\mathrm{pH}$}

It was observed that the $\mathrm{pH}$ of gastric contents has been markedly decreased in the Diseased control (group II) when compared to Control group (group I) and increased significantly in Standard drug treated (group III) and E. hyemale ethanolic extracts treated groups (groups IV and V) (Table I).

\section{Total acidity}

It was observed that total acidity has been markedly increased in Diseased control (group II) as compared to Control group (group I) and decreased greatly in E. hyemale ethanolic extracts treated groups (groups IV and V) (Table II).

\section{Macroscopic Evaluation}

It was observed that there was marked decrease in the damage produced by ulcer in standard drug treated (group III), E. hyemale ethanolic extract treated groups (groups IV and V) as compared to the Diseased control (group II) (Table III). 
Determination of $\mathrm{pH}$ of gastric contents from Control (group I), Diseased control (group II), Standard drug treated (group III), E. hyemale ( $250 \mathrm{mg} / \mathrm{kg}$ bw and $500 \mathrm{mg} / \mathrm{kg} \mathrm{bw}$ ) extract treated groups (groups IV and V)

\begin{tabular}{|c|c|c|c|c|c|}
\hline & $\begin{array}{c}\text { Group I } \\
\text { Parameters }\end{array}$ & $\begin{array}{c}\text { Group II } \\
(\text { Mean } \pm \text { SEM })\end{array}$ & $\begin{array}{c}\text { Group III } \\
(\text { Mean } \pm \text { SEM })\end{array}$ & $\begin{array}{c}\text { Group IV } \\
(\text { Mean } \pm \text { SEM })\end{array}$ & $\begin{array}{c}\text { Group V } \\
(\text { Mean } \pm \text { SEM })\end{array}$ \\
\hline $\mathrm{pH}$ & $5.75 \pm 0.25$ & $3.00 \pm 0.40^{*}$ & $5.00 \pm 0.40^{* * *}$ & $5.0 \pm 0.40^{* *}$ & $6.0 \pm 0.40^{* * *}$ \\
\hline
\end{tabular}

Table II

Determination of total acidity of gastric contents from Control (group I), Diseased control (group II), Standard drug treated (group III), E. hyemale $(250 \mathrm{mg} / \mathrm{kg}$ bw and $500 \mathrm{mg} / \mathrm{kg}$ bw) extract treated groups (groups IV and V)

\begin{tabular}{|c|c|c|c|c|c|}
\hline $\begin{array}{c}\text { Parameters } \\
\text { (Mean } \pm \text { SEM) }\end{array}$ & $\begin{array}{c}\text { Group I } \\
(\text { Mean } \pm \text { SEM })\end{array}$ & $\begin{array}{c}\text { Group III } \\
(\text { Mean } \pm \text { SEM })\end{array}$ & $\begin{array}{c}\text { Group IV } \\
(\text { Mean } \pm \text { SEM })\end{array}$ & $\begin{array}{c}\text { Group V } \\
(\text { Mean } \pm \text { SEM })\end{array}$ \\
\hline Total acidity $(\mathrm{mEq} / \mathrm{L})$ & $17.80 \pm 0.56$ & $38.77 \pm 0.48^{*}$ & $25.45 \pm 0.45^{* *}$ & $33.95 \pm 0.47^{* *}$ & $24.42 \pm 0.27^{* *}$ \\
\hline
\end{tabular}

Table III

Ulcer scores calculated for Control (group I), Diseased control (group II), Standard drug treated (group III), $E$. hyemale $(250 \mathrm{mg} / \mathrm{kg} \mathrm{bw}$ and $500 \mathrm{mg} / \mathrm{kg} \mathrm{bw}$ ) extract treated groups (groups IV and V)

\begin{tabular}{|c|c|c|c|c|c|}
\hline & $\begin{array}{c}\text { Group I } \\
\text { Parameters }\end{array}$ & $\begin{array}{c}\text { Group II } \\
(\text { Mean } \pm \text { SEM })\end{array}$ & $\begin{array}{c}\text { Group III } \\
(\text { Mean } \pm \text { SEM })\end{array}$ & $\begin{array}{c}\text { Group IV } \\
(\text { Mean } \pm \text { SEM })\end{array}$ & $\begin{array}{c}\text { Group V } \\
(\text { Mean } \pm \text { SEM })\end{array}$ \\
\hline Ulcer score & $0.00 \pm 0.00$ & $1.62 \pm 0.12^{*}$ & $0.37 \pm 0.23^{* *}$ & $0.37 \pm 0.12^{* * *}$ & $0.50 \pm 0.20^{* * *}$ \\
\hline
\end{tabular}

\section{Determination of ulcer index}

The ulcer index was determined from gastric tissues of Control, Disease control, Standard drug treated and ethanolic extract of E. hyemale $(250 \mathrm{mg} / \mathrm{kg}$ bw and $500 \mathrm{mg} / \mathrm{kg} \mathrm{bw}$ ) treated groups. It was observed that ulcer index was markedly reduced in standard drug treated (group III) and in E. hyemale $(250 \mathrm{mg} / \mathrm{kg}$ bw and $500 \mathrm{mg} / \mathrm{kg} \mathrm{bw}$ ) treated groups (groups IV and $\mathrm{V})$ as shown in Table IV.

\section{Histopathological evaluation}

The histopathological evaluation of the animals' gastric tissue with ethanol induced ulcer is presented in Figure 1.
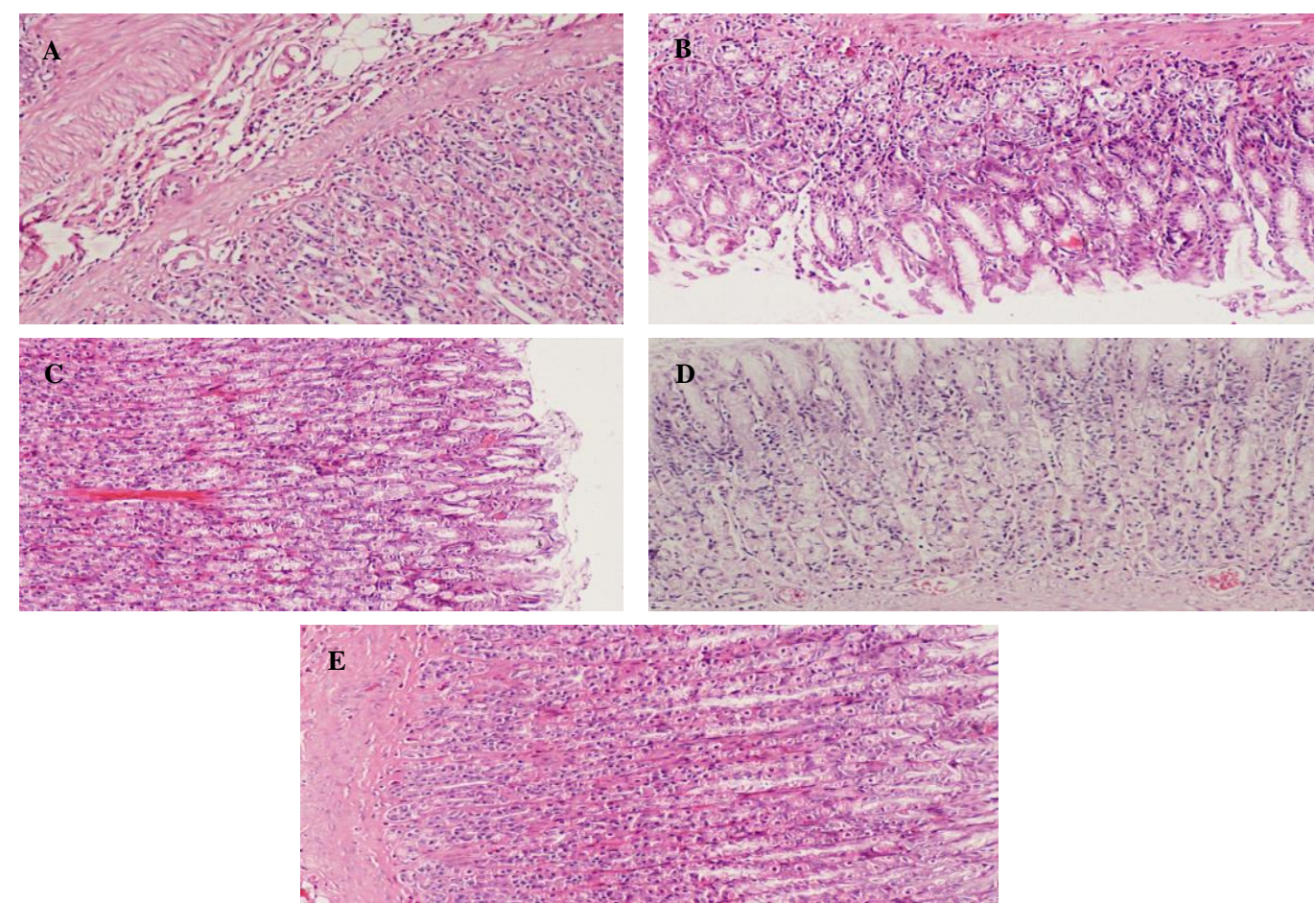

Figure 1.

Effect of Equisetum hyemale on the morphology of stomach cells. Histopathological examination of rat stomachs of Control (A), Diseased control (B), Standard drug control (C), E. hyemale $250 \mathrm{mg} / \mathrm{kg}$ bw (D), E. hyemale 500 $\mathrm{mg} / \mathrm{kg}$ bw (E) 
Ulcer index (UI) for Control (group I), Diseased control (group II), Standard drug treated (group III), E. hyemale $(250 \mathrm{mg} / \mathrm{kg}$ bw and $500 \mathrm{mg} / \mathrm{kg} \mathrm{bw}$ ) extract treated groups (groups IV and V)

\begin{tabular}{|c|c|c|c|c|}
\hline Groups & $\mathbf{U}_{\mathbf{n}}$ & $\mathbf{U}_{\mathbf{s}}$ & $\mathbf{U}_{\mathbf{p}}$ & $\mathbf{U I}$ \\
\hline I & 0 & 0 & 0 & $0 \pm 0.0$ \\
\hline II & 13.75 & 3 & 100 & $11.6 \pm 1.1^{*}$ \\
\hline III & 7.0 & 1 & 50 & $5.8 \pm 0.81^{* * *}$ \\
\hline IV & 8.25 & 3 & 50 & $6.12 \pm 1.1^{* * *}$ \\
\hline V & 8.0 & 2 & 50 & $6.0 \pm 1.08^{* * *}$ \\
\hline
\end{tabular}

$\mathrm{U}_{\mathrm{n}}=$ average no of ulcers per animal, $\mathrm{U}_{\mathrm{s}}=$ average no of severity of scores, $\mathrm{U}_{\mathrm{p}}=$ percentage of animals with ulcer ${ }^{*} \mathrm{p}<0.05$ compared to the normal control group; ${ }^{* *} \mathrm{p}<0.05$ compared to diseased control group; $\mathrm{n}=4$

Abnormal texture of columnar epithelium and no change in glandular structure were observed (A). Necrotic changes, gastric lesions and induction of ulcers were seen in the epithelial cells and glandular cells in the diseased control group (B). Haemorrhages were confined to the superficial layer of mucosa only in standard drug treated group $(\mathbf{C})$, also ulcers were present, but the severity of damage was minor. The ulcers were confined to the upper part of the glands only in E. hyemale extract treated $(250 \mathrm{mg} / \mathrm{kg}$ bw) group (D), with small necrotic changes in mucosal cells, but glands were normal. Haemorrhage in lamina propria were present, but limited to a small area, and no deeper lesions or ulcer were seen in E. hyemale extract treated $(500 \mathrm{mg} / \mathrm{kg} \mathrm{bw})$ group of rats $(\mathbf{E})$.

ASA induced ulcer model

Determination of $\mathrm{pH}$

It was observed that the $\mathrm{pH}$ of gastric content is markedly reduced in the Diseased control (group II) as compared to Control (group I) and increased significantly in Standard drug treated (group III) and extracts treated groups (group IV and V) as shown in Table V.

Table V

Determination of $\mathrm{pH}$ of gastric contents from Control (group I), Diseased control (group II), Standard drug treated (group III), E. hyemale ( $250 \mathrm{mg} / \mathrm{kg}$ bw and $500 \mathrm{mg} / \mathrm{kg} \mathrm{bw}$ ) extract treated groups (groups IV and V)

\begin{tabular}{|c|c|c|c|c|c|}
\hline Parameters & $\begin{array}{c}\text { Group I } \\
(\text { Mean } \pm \text { SEM })\end{array}$ & $\begin{array}{c}\text { Group II } \\
(\text { Mean } \pm \text { SEM })\end{array}$ & $\begin{array}{c}\text { Group III } \\
(\text { Mean } \pm \text { SEM })\end{array}$ & $\begin{array}{c}\text { Group IV } \\
(\text { Mean } \pm \text { SEM })\end{array}$ & $\begin{array}{c}\text { Group V } \\
(\text { Mean } \pm \text { SEM })\end{array}$ \\
\hline pH & $5.50 \pm 0.28$ & $3.75 \pm 0.25^{*}$ & $5.75 \pm 0.47^{* *}$ & $6.00 \pm 0.40^{* *}$ & $6.50 \pm 0.28^{* *}$ \\
\hline
\end{tabular}

" $\mathrm{p}<0.05$ compared to the normal control group; ${ }^{* *} \mathrm{p}<0.05$ compared to diseased control group; $\mathrm{n}=4$

Total acidity

The total acidity was measured for Control, Diseased control, Standard drug treated, E. hyemale $(250 \mathrm{mg} / \mathrm{kg}$ bw and $500 \mathrm{mg} / \mathrm{kg} \mathrm{bw}$ ) extract treated groups. It was observed that the total acidity has been greatly enhanced in the Diseased control (group II) as compared to control (group I) and decreased significantly in Standard treatment control (group III) and extracts treated groups (groups IV and V) (Table VI).

Determination of total acidity of gastric contents from Control (group I), Diseased control (group II), Standard drug treated (group III), E. hyemale $(250 \mathrm{mg} / \mathrm{kg}$ bw and $500 \mathrm{mg} / \mathrm{kg}$ bw) extract treated groups (group IV and V

\begin{tabular}{|c|c|c|c|c|c|}
\hline & $\begin{array}{c}\text { Group I } \\
\text { Parameters }\end{array}$ & $\begin{array}{c}\text { Group II } \\
\text { (Mean } \pm \text { SEM) }\end{array}$ & $\begin{array}{c}\text { Group III } \\
(\text { Mean } \pm \text { SEM) }\end{array}$ & $\begin{array}{c}\text { Group IV } \\
(\text { Mean } \pm \text { SEM) }\end{array}$ & $\begin{array}{c}\text { Group V } \\
(\text { Mean } \pm \text { SEM })\end{array}$ \\
\hline Total acidity $(\mathrm{mEq} / \mathrm{L})$ & $36.65 \pm 0.40$ & $64.27 \pm 0.49^{*}$ & $61.2 \pm 0.30^{* *}$ & $54.12 \pm 0.47^{* * *}$ & $49.97 \pm 0.53^{* *}$ \\
\hline
\end{tabular}

\section{Macroscopic evaluation}

Gastric tissues were macroscopically evaluated for damage or lesions presence by comparing the stomachs of Control, Diseased control, Standard drug treated, $E$. hyemale $(250 \mathrm{mg} / \mathrm{kg}$ bw extract and $500 \mathrm{mg} / \mathrm{kg} \mathrm{bw})$ extract treated groups. It was noticed a great reduction in the damage produced by ulcer in the extract treated groups (groups IV and V) as compared to the Diseased control (group II), as shown in Table VII.

Table VII

Ulcer scores calculated for Control (group I), Diseased control (group II), Standard drug treated (group III), E. hyemale $(250 \mathrm{mg} / \mathrm{kg}$ bw and $500 \mathrm{mg} / \mathrm{kg} \mathrm{bw}$ ) extract treated groups (groups IV and V)

\begin{tabular}{|c|c|c|c|c|c|}
\hline Parameters & $\begin{array}{c}\text { Group I } \\
(\text { Mean } \pm \text { SEM })\end{array}$ & $\begin{array}{c}\text { Group II } \\
(\text { Mean } \pm \text { SEM })\end{array}$ & $\begin{array}{c}\text { Group III } \\
(\text { Mean } \pm \text { SEM })\end{array}$ & $\begin{array}{c}\text { Group IV } \\
(\text { Mean } \pm \text { SEM })\end{array}$ & $\begin{array}{c}\text { Group V } \\
(\text { Mean } \pm \text { SEM })\end{array}$ \\
\hline Ulcer score & $0.00 \pm 0.00$ & $1.25 \pm 0.14^{*}$ & $0.50 \pm 0.20^{* *}$ & $0.50 \pm 0.20^{* *}$ & $0.37 \pm 0.12^{* *}$ \\
\hline
\end{tabular}


Ulcer index

The ulcer index was determined from gastric tissues of Control, Diseased control, Standard drug treated and ethanolic extract of $E$. hyemale $(250 \mathrm{mg} / \mathrm{kg}$ bw and $500 \mathrm{mg} / \mathrm{kg} \mathrm{bw}$ ) treated groups (groups IV and V). It was noticed that the ulcer index was markedly decreased in standard drug treated (group III) and in
E. hyemale $(250 \mathrm{mg} / \mathrm{kg}$ bw and $500 \mathrm{mg} / \mathrm{kg} \mathrm{bw})$ treated groups as shown in Table VIII.

Histopathological study

The histopathological study of the stomachs from control, Diseased, Standard drug and E. hyemale extract treated groups has been carried out (Figure 2).

The ulcer index (UI) from samples of stomach from control (group I), Diseased control (group II), Standard drug treated (group III), E. hyemale $(250 \mathrm{mg} / \mathrm{kg}$ bw and $500 \mathrm{mg} / \mathrm{kg}$ bw) extract treated groups (groups IV and V)

\begin{tabular}{|c|c|c|c|c|}
\hline Groups & $\mathbf{U}_{\mathbf{n}}$ & $\mathbf{U}_{\mathbf{s}}$ & $\mathbf{U}_{\mathbf{p}}$ & $\mathbf{U I}$ \\
\hline I & 0 & 0 & 0 & $0 \pm 0.0$ \\
\hline II & 16.5 & 3 & 100 & $11.95 \pm 0.64^{* *}$ \\
\hline III & 8.5 & 1 & 50 & $5.95 \pm 0.64^{* * *}$ \\
\hline IV & 9.5 & 3 & 50 & $6.25 \pm 0.64^{* * *}$ \\
\hline V & 10.2 & 2 & 50 & $6.27 \pm 0.47^{* * *}$ \\
\hline
\end{tabular}

$\mathrm{U}_{\mathrm{n}}=$ average no of ulcers per animal, $\mathrm{U}_{\mathrm{s}}=$ average no of severity of scores, $\mathrm{U}_{\mathrm{p}}=$ percentage of animals with ulcer ${ }^{*} \mathrm{p}<0.05$ compared to the normal control group; ${ }^{* *} \mathrm{p}<0.05$ compared to diseased control group; $\mathrm{n}=4$
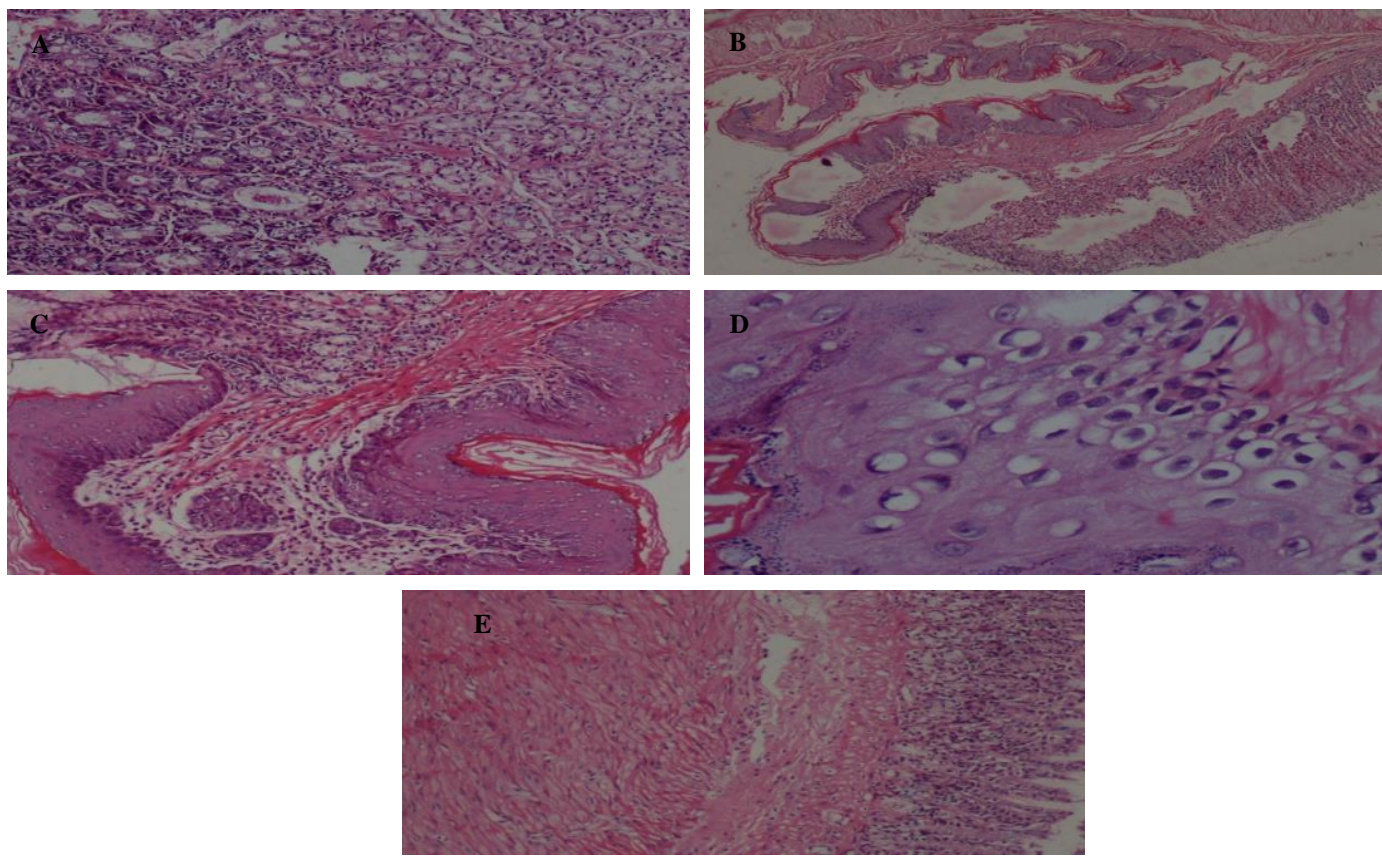

Figure 2.

Effect of Equisetum hyemale on the morphology of stomach cells. Histopathological examination of rat stomachs of Control (A), Diseased control (B), standard drug control (C), E. hyemale $250 \mathrm{mg} / \mathrm{kg}$ bw (D), E. hyemale 500 $\mathrm{mg} / \mathrm{kg}$ bw (E) treated groups

The gastric mucosa was normal presenting high columnar epithelium. There was no necrotic or degenerated tissue, glandular texture was also intact $(\mathbf{A})$, sloughing of epithelium and haemorrhage of submucosa. Corrosion of epithelium at multiple foci was seen, extending to muscularis layer, oedematous. Necrotic cellular debris were present, cellular annexure was disrupted. Metaplasia of epithelium seen in the Diseased control group (B), multiple sections of epithelium showed normal architecture with slight oedematous area. Slight haemorrhage and cellular debris also seen in some area. Necrotic changes were seen in small area of epithelium. No ulcer was seen in Standard drug treated group (C), slight necrotic area was present with extensive vascularisation. No ulceration was observed. Most of the epithelium was normal with regular cells in E. hyemale extract $(250 \mathrm{mg} / \mathrm{kg} \mathrm{bw})$ treated group (D), most area of epithelium was intact. No micro haemorrhages were found. Less intensity of vascularisation, no ulcer was seen in E. hyemale extract $(500 \mathrm{mg} / \mathrm{kg} \mathrm{bw})$ treated groups $(\mathbf{E})$.

Pylorus ligation induced ulcer model

\section{Determination of $\mathrm{pH}$}

It was observed that the $\mathrm{pH}$ of gastric content has been greatly reduced in the Diseased control (group II) as compared to Control (group I) and enhanced significantly in the extracts treated groups (groups IV and V) as shown in Table IX. 
Table IX

Determination of $\mathrm{pH}$ of gastric contents from Control (group I), Diseased control (group II), Standard drug treated (group III), E. hyemale $(250 \mathrm{mg} / \mathrm{kg}$ bw and $500 \mathrm{mg} / \mathrm{kg} \mathrm{bw}$ ) extract treated groups (groups IV and V)

\begin{tabular}{|c|c|c|c|c|c|}
\hline Parameters & $\begin{array}{c}\text { Group I } \\
(\text { Mean } \pm \text { SEM })\end{array}$ & $\begin{array}{c}\text { Group II } \\
(\text { Mean } \pm \text { SEM })\end{array}$ & $\begin{array}{c}\text { Group III } \\
(\text { Mean } \pm \text { SEM })\end{array}$ & $\begin{array}{c}\text { Group IV } \\
(\text { Mean } \pm \text { SEM })\end{array}$ & $\begin{array}{c}\text { Group V } \\
(\text { Mean } \pm \text { SEM })\end{array}$ \\
\hline $\mathrm{pH}$ & $5.75 \pm 0.25$ & $3.75 \pm 0.47^{*}$ & $5.50 \pm 0.28^{* *}$ & $5.75 \pm 0.25^{* * *}$ & $6.0 \pm 0.40^{* * *}$ \\
\hline
\end{tabular}

\section{Total acidity}

It was observed that total acidity was markedly increased in the Diseased control (group II) as compared to Control (group I) and decreased considerably in Standard drug treated (group III) and extracts treated groups (groups IV and V) (Table X).

Table X

Determination of total acidity of gastric contents from Control (group I), Diseased control (group II), Standard drug treated (group III), E. hyemale $(250 \mathrm{mg} / \mathrm{kg}$ bw and $500 \mathrm{mg} / \mathrm{kg} \mathrm{bw}$ ) extract treated groups (groups IV and V)

\begin{tabular}{|c|c|c|c|c|c|}
\hline & $\begin{array}{c}\text { Group I } \\
\text { Parameters }\end{array}$ & $\begin{array}{c}\text { Group II } \\
\text { (Mean } \pm \text { SEM) }\end{array}$ & $\begin{array}{c}\text { Group III } \\
(\text { Sean } \pm \text { SEM) }\end{array}$ & $\begin{array}{c}\text { Group IV } \\
(\text { Mean } \pm \text { SEM) }\end{array}$ & $\begin{array}{c}\text { Group V } \\
(\text { Mean } \pm \text { SEM) }\end{array}$ \\
\hline Total acidity $(\mathrm{mEq} / \mathrm{L})$ & $8.55 \pm 0.34$ & $39.07 \pm 0.40^{*}$ & $29.62 \pm 0.60^{* * *}$ & $14.37 \pm 0.60^{* * *}$ & $7.47 \pm 0.40^{* *}$ \\
\hline
\end{tabular}

\section{Macroscopic evaluation}

It was observed a significant reduction in the damage produced by ulcer in the extract treated groups (groups IV and V) as compared to the Diseased control group (Table XI).
Ulcer index

It was noticed that the ulcer index was markedly decreased in Standard drug treated (group III) and in E. hyemale $(250 \mathrm{mg} / \mathrm{kg}$ bw and $500 \mathrm{mg} / \mathrm{kg} \mathrm{bw})$ treated groups (groups IV and V) as shown in Table XII.

Table XI

Ulcer scores from Control (group I), Diseased control (group II), Standard drug treated (group III), E. hyemale $(250 \mathrm{mg} / \mathrm{kg}$ bw and $500 \mathrm{mg} / \mathrm{kg} \mathrm{bw}$ ) extract treated groups (groups IV and V)

\begin{tabular}{|c|c|c|c|c|c|}
\hline Parameters & $\begin{array}{c}\text { Group I } \\
(\text { Mean } \pm \text { SEM })\end{array}$ & $\begin{array}{c}\text { Group II } \\
(\text { Mean } \pm \text { SEM })\end{array}$ & $\begin{array}{c}\text { Group III } \\
(\text { Mean } \pm \text { SEM) }\end{array}$ & $\begin{array}{c}\text { Group IV } \\
(\text { Mean } \pm \text { SEM })\end{array}$ & $\begin{array}{c}\text { Group V } \\
(\text { Mean } \pm \text { SEM })\end{array}$ \\
\hline Ulcer score & $0.00 \pm 0.00$ & $1.5 \pm 0.2^{*}$ & $0.38 \pm 0.0 .23^{* *}$ & $0.5 \pm 0.20^{* *}$ & $0.37 \pm 0.23^{* *}$ \\
\hline
\end{tabular}

Table XII

Calculation of ulcer index (UI) from Control (group I), Diseased control (group II), Standard drug treated (group III), E. hyemale ( $250 \mathrm{mg} / \mathrm{kg} \mathrm{bw}$ and $500 \mathrm{mg} / \mathrm{kg} \mathrm{bw}$ ) extract treated groups (groups IV and V)

\begin{tabular}{|c|c|c|c|c|}
\hline Groups & $\mathbf{U}_{\mathbf{n}}$ & $\mathbf{U}_{\mathbf{s}}$ & $\mathbf{U}_{\mathbf{p}}$ & $\mathbf{U I}$ \\
\hline I & 0 & 0 & 0 & 0 \\
\hline II & 25.66 & 3 & 100 & $12.88 \pm 1.76^{*}$ \\
\hline III & 15.0 & 1 & 50 & $6.60 \pm 4.08^{* * *}$ \\
\hline IV & 14.50 & 3 & 50 & $6.75 \pm 1.04^{* *}$ \\
\hline V & 11.5 & 2 & 50 & $6.35 \pm 1.04^{\text {** }}$ \\
\hline
\end{tabular}

$\mathrm{U}_{\mathrm{n}}=$ average no of ulcers per animal, $\mathrm{U}_{\mathrm{s}}$ average no of severity of scores, $\mathrm{U}_{\mathrm{p}=\text { percentage of animals with ulcer }}$ ${ }^{*} \mathrm{p}<0.05$ compared to the normal control group; ${ }^{* *} \mathrm{p}<0.05$ compared to diseased control group; $\mathrm{n}=4$

\section{Histopathological study}

Histopathological study of the stomachs from the control, Diseased, Standard drug and E. hyemale extract treated groups has been carried out (Figure 3). The gastric mucosa of the stomach tissues in the Control group showed normal high columnar epithelium. The gastric glandular structure was normal and intact. No necrotic or degenerated tissue was observed in the whole thickness of mucosa (A). In Diseased group (B) there were necrotic changes in the whole thickness of mucosa.

Necrotic cells with more eosinophilic homogeneous cytoplasm were seen. Some cells also showed hydropic degeneration. A few cells showed pyknotic nuclei (B), in the Standard drug treated group of rats, some cells were transformed from one type of epithelial shape to another form.

Some mononuclear inflammatory cells were seen. Necrosis and degeneration in the glands limited to superficial area only $(\mathbf{C})$. The stomachs showed necrotic changes in mucosal layer. Some glandular tissues also showed degeneration. A few inflammatory cells were also seen in E. hyemale ( $250 \mathrm{mg} / \mathrm{kg} \mathrm{bw})$ extract treated group (D). The stomachs showed less necrotic changes in the mucosal layer. Some glandular tissues also showed degeneration. A few inflammatory cells were also seen $(\mathbf{E})$.

The protection and ulcer indexes for the animals used in the ulcers induced models, based on ulcers index measurements, are summarised in Table XIII. 

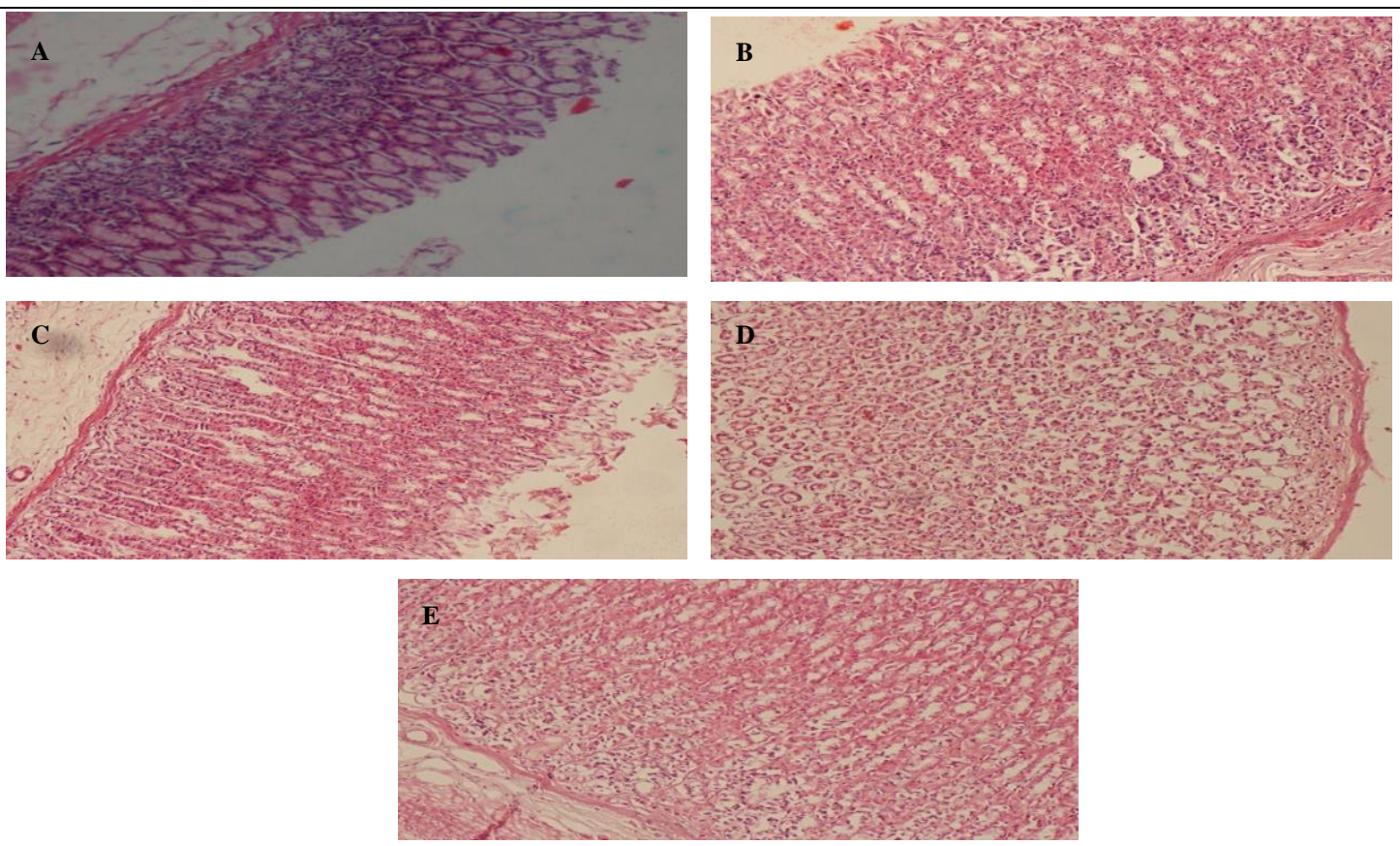

Figure 3.

Effect of Equisetum hyemale on the morphology of stomach cells. Histopathological examination of rat stomachs of Control (A), Diseased control (B), Standard drug control (C), E. hyemale $250 \mathrm{mg} / \mathrm{kg}$ bw (D), E. hyemale 500 $\mathrm{mg} / \mathrm{kg}$ bw (E) treated groups

Table XIII

Protection (\%) against ethanol, ASA and pylorus ligation induced gastric ulcer by sucralfate (group III), E. hyemale $250 \mathrm{mg} / \mathrm{kg}$ bw (group IV), E. hyemale $500 \mathrm{mg} / \mathrm{kg}$ bw (group V) based on ulcers index measurements

\begin{tabular}{|c|c|c|c|c|c|c|}
\hline \multirow{2}{*}{ Groups } & \multicolumn{2}{|c|}{ Ethanol induced ulcer } & \multicolumn{2}{c|}{ ASA induced ulcer } & \multicolumn{2}{c|}{ Pylorus ligation induced ulcer } \\
\cline { 2 - 7 } & Ulcer index & Protection (\%) & Ulcer index & Protection (\%) & Ulcer index & Protection (\%) \\
\hline I & 0 & 0 & 0 & 0 & 0 & 0 \\
\hline II & 11.6 & 0 & 11.95 & 0 & 12.88 & 0 \\
\hline III & 5.8 & 50 & 5.95 & 50 & 6.60 & 48.7 \\
\hline IV & 6.12 & 47.2 & 6.25 & 47.7 & 6.75 & 47.6 \\
\hline V & 6.0 & 48.2 & 6.27 & 47.5 & 6.35 & 50.7 \\
\hline
\end{tabular}

In all cultures, people used plants as a source of medicine [20]. Initially people used herbs to fulfil their nutritional needs, but with the passage of time, these herbs become a good source to treat and prevent different health issues in different human communities. Different plants species are being used worldwide such as in Asia, South America and Africa for cures against medical ailments [21]. According to WHO, $60 \%$ of the world population prefer to use traditional medicines in primary health care system, however there are many plants still undiscovered with good potential of biological properties [22].

Equisetum hyemale L. (E. hyemale) is one of the members of genus Equisetum, the only surviving representative of Sphenopsida class [10]. E. hyemale has been used in stomach pain traditionally, but this action has not been fully investigated and described.

The alcohol induced ulcer model was first studied in 1985 Hollander D et al. The animal model is not influenced by secretions of gastric acid and becomes closely related to acute peptic ulcers. This model is useful for evaluating the effectiveness of substances which have cell protection and oxidation limiting abilities [23]. In the current study, $\mathrm{pH}$ of gastric contents of stomach from E. hyemale $(250 \mathrm{mg} / \mathrm{kg}$ bw and $500 \mathrm{mg} / \mathrm{kg} \mathrm{bw}$ ) ethanolic extract treated groups has been increased towards more basic $(66.67 \%$ and $100 \%$, respectively) compared to Diseased control group as shown in Table I. Total acidity of gastric contents of stomach from E. hyemale $(250 \mathrm{mg} / \mathrm{kg}$ bw and $500 \mathrm{mg} / \mathrm{kg} \mathrm{bw}$ ) ethanolic extract treated groups has been decreased $(12.43 \%$ and $37.0 \%)$ respectively as compared to the Diseased control group as shown in Table II. These results were in accordance with the previous studies [24]. Macroscopic evaluation showed decrease gastric lesions $(77.16 \%$ and $69.13 \%)$ in $E$. hyemale $(250 \mathrm{mg} / \mathrm{kg}$ bw and $500 \mathrm{mg} / \mathrm{kg}$ bw) ethanolic extract treated groups respectively, as shown in Table III. Ulcer index was also reduced significantly in $E$. hyemale ethanolic extract treated groups at both doses (47.24\% and $48.27 \%$ ) respectively as compared to Standard drug treated group (50.0\%) as shown in Table IV. These results are comparable with the previous studies [24]. 
FARMACIA, 2021, Vol. 69, 2

Histopathological studies showed that alcohol produced haemorrhagic gastric lesions, extensive submucosal oedema and inflammatory changes in the whole mucosa extending to the deeper layer. Administration of ethanol leads to the decrease of blood flow and caused disturbance of vessel, resulting in bleeding of gastric mucosa and necrosis [25]. These changes have been ameliorated in E. hyemale extract treated groups as shown in Figure 1. Gastroprotective effect of E. hyemale in ethanol-induced ulcer rat model might be due to antioxidant and anti-inflammatory activities of phytochemicals present in the ethanolic extract of $E$. hyemale [26].

The ASA induced ulcer model is important in considering the effectiveness of the anti-secretory and cytoprotective agent as it works on secretion of gastric acid and synthesis of prostaglandins. Among NSAIDs, most commonly used agent is ASA [27]. In current study, $\mathrm{pH}$ of gastric contents of stomachs from E. hyemale ( $250 \mathrm{mg} / \mathrm{kg}$ bw and $500 \mathrm{mg} / \mathrm{kg} \mathrm{bw})$ ethanolic extract treated groups also showed a marked change towards basic side $(60 \%$ and $73.33 \%$ ) respectively as compared to Diseased control group as shown in Table V. It was noticed that total acidity of gastric contents of stomach of E. hyemale $(250 \mathrm{mg} / \mathrm{kg}$ bw and $500 \mathrm{mg} / \mathrm{kg} \mathrm{bw})$ ethanolic extract treated groups was reduced $(15.79 \%$ and $22.24 \%$ ) respectively as compared to the Diseased control group as shown in Table VI. The results of macroscopic evaluation of stomachs from Control, Disease control, Standard drug treated group and $E$. hyemale ( 250 and $500 \mathrm{mg} / \mathrm{kg} \mathrm{bw}$ ) extract treated groups expressed gastroprotective effect in ASA induced gastric ulcer model. A reduction in the severity of ulcer (60\% and $70.4 \%$ ) in E. hyemale (250 and 500 $\mathrm{mg} / \mathrm{kg} \mathrm{bw}$ ) extract treated groups has been observed respectively as shown in Table VII. Ulcer index was also reduced significantly in E. hyemale $(250 \mathrm{mg} / \mathrm{kg}$ bw and $500 \mathrm{mg} / \mathrm{kg} \mathrm{bw}$ ) ethanolic extract treated groups $(47.69 \%$ and $47.53 \%)$ respectively as compared to Standard drug treated group $(50.2 \%)$ as shown in Table VIII. Histopathological examination of rats' stomachs from the control group showed that gastric mucosa was normal, presenting high columnar epithelium. There was no necrotic or degeneration. However, sloughing of epithelium and haemorrhage of submucosa, corrosion of epithelium at multiple foci were seen in the Diseased control group. No ulcer was seen in the Standard drug treated group and similar findings have been observed in E. hyemale extract treated groups of rats as shown in Figure 2. The aqueous ethanolic extract of Equisetum hyemale might prevent binding of histamine to $\mathrm{H}_{2}$ receptors and lead to decrease secretion of gastric acid. Gastroprotective potential of $E$. hyemale might also be due to suppression of ASA inhibitory effect on prostaglandins secretion [28-30].
Pylorus ligation induced ulcer model is a commonly used model for studying the efficiency of drugs on acid secretions. Gastric acid is accumulated in the stomach by the ligation of pyloric end, resulting in ulcers incidence [15]. In the present study, $\mathrm{pH}$ of gastric contents of stomachs from $E$. hyemale $(250$ and $500 \mathrm{mg} / \mathrm{kg}$ bw extract) treated groups showed a marked increase in $\mathrm{pH}(53.33 \%$ and $60 \%$, respectively) as compared to the Diseased control group (33.3\%) as shown in Table IX. It was noticed that total acidity of gastric contents of stomachs of E. hyemale (250 and $500 \mathrm{mg} / \mathrm{kg} \mathrm{bw})$ extract treated groups was reduced (63.21\% and $80.8 \%)$ as compared to the Diseased control group (78.11\%) as shown in Table X. These results were supported by previous studies [18]. Macroscopic evaluation findings showed a decrease in gastric lesions $(66.6 \%$ and $75.33 \%)$ in E. hyemale extract (250 and $500 \mathrm{mg} / \mathrm{kg}$ bw) treated groups respectively in pylorus ligation induced ulcer model as shown in Table XI. The ulcer index was also reduced significantly in $E$. hyemale ethanolic extract (250 and $500 \mathrm{mg} / \mathrm{kg} \mathrm{bw}$ ) treated groups (47.59\% and $50.69 \%$ ) respectively as compared to Standard drug treated group $(48.75 \%)$ as shown in Table XII. In histopathology studies, gastric glandular structure was normal and intact. No necrotic or degeneration was seen in whole thickness of mucosa in control group as compared to the Diseased group where necrotic changes were present in the whole thickness of mucosa. Some cells also showed hydropic degeneration. In Standard drug treated group, some cells were transformed from one type of epithelial shape to another form. Some mononuclear inflammatory cells were seen. Necrosis and degeneration in the glands were limited to the superficial area and $E$. hyemale extracts treated groups showed less necrotic changes in mucosal layer. Some glandular tissues also showed degeneration. A few inflammatory cells were also seen (Figure 3). In the pylorus ligation induced ulcer, gastroprotective potential of $E$. hyemale might involve increase level of mucus, preventing ulcer formation by buffering gastric acid and strengthening of the gastric mucosal protection [31]. Overall, the aqueous ethanolic extract of $E$. hyemale presented an average of $47.5 \%$ and $48.8 \%$ protection at 250 and $500 \mathrm{mg} / \mathrm{kg}$ bw doses respectively in all three gastric ulcer models as shown in Table XIII.

\section{Conclusions}

The present study indicates that the ethanolic extract of Equisetum hyemale attenuated ethanol, ASA and pylorus ligation induced gastric ulcers and normalized histopathologic changes in rat's stomachs. The proposed mechanisms of gastroprotection by $E$. hyemale against different ulcer models involve the decrease of oxidation processes of membrane phospholipids, prevention of $\mathrm{H}_{2}$ receptors activation, the increase of prostaglandins 
secretion and formation of mucus layer. Overall, the findings of the present study supported the beneficial effects of E. hyemale in preventing the development of gastric ulcer in experimental models, thus opening the possibility of its us as an alternative therapy for gastric ulcer.

\section{Conflict of interest}

The authors declare no conflict of interest.

\section{References}

1. Farzaei MH, Abdollahi M, Rahimi R, Role of dietary polyphenols in the management of peptic ulcer. World J Gastroenterol., 2015; 21(21): 6499-6517.

2. Pereira Barbosa JA, Nascimento Santana MA, Campos Leite TC, de Oliveira TB, Barreto Mota FV, Gomes Alves Bastos IV, Corrêa AJC, de Amorim ELC, Cardoso Vieira JR, Sarmento Silva TM, Bandeira Delmiro Santana AL, do Nascimento MS, da Silva TG, Gastroprotective effect of ethyl acetate extract from Avicennia schaueriana Stapf \& Leechman and underlying mechanisms. Biomed Pharmacother., 2019; 112: 108582: 1-10.

3. Lima ZP, Severi JA, Pellizzon CH, Brito AR, Solis PN, Cáceres A, Girón LM, Vilegas W, Hiruma-Lima $\mathrm{CA}$, Can the aqueous decoction of mango flowers be used as an antiulcer agent?. J Ethnopharmacol., 2006; 106(1): 29-37.

4. Bandyopadhyay D, Chattopadhyay A, Reactive oxygen species-induced gastric ulceration: protection by melatonin. Curr Med Chem., 2006; 13(10): 11871202.

5. Bighetti AE, Antônio MA, Kohn LK, Rehder VL, Foglio MA, Possenti A, Vilela L, Carvalho JE, Antiulcerogenic activity of a crude hydroalcoholic extract and coumarin isolated from Mikania laevigata Schultz Bip. Phytomedicine, 2005; 12(1-2): 72-77.

6. Lakshmi V, Singh N, Shrivastva S, Mishra SK, Dharmani P, Mishra V, Gedunin and photogedunin of Xylocarpus granatum show significant anti-secretory effects and protect the gastric mucosa of peptic ulcer in rats. Phytomedicine, 2010; 17(8-9): 569-574.

7. Falcão HS, Mariath IR, Diniz MF, Batista LM, Barbosa-Filho JM, Plants of the American continent with antiulcer activity. Phytomedicine, 2008; 15(1-2): 132-146.

8. Fons F, Froissard D, Bessière JM, Fruchier A, Buatois B, Rapior S, Volatile composition of six horsetails: prospects and perspectives. Nat Prod Commun., 2013; 8(4): 509-512.

9. Santos MG, Kelecom A, Paiva SR, Moraes MG, Rocha L, Garrett R, Phytochemical studies in pteridophytes growing in Brazil: A review. Am J Plant Sci Biotech., 2010; 4: 113-125.

10. Gierlinger N, Sapei L, Paris O, Insights into the chemical composition of Equisetum hyemale by high resolution Raman imaging. Planta, 2008; 227(5): 969-980.

11. Singh V, Singh N, Pal US, Dhasmana S, Mohammad S, Singh N, Clinical evaluation of Cissus quadrangularis and Moringa oleifera and osteoseal as osteogenic agents in mandibular fracture. Natl J Maxillofac Surg., 2011; 2(2): 132-136.

12. Sheweita SA, Khoshhal KI, Calcium metabolism and oxidative stress in bone fractures: role of antioxidants. Curr Drug Metab., 2007; 8(5): 519-525.

13. Sattar A, Abdo A, Mushtaq MN, Anjum I, Anjum A, Evaluation of Gastro-protective Activity of Myristica fragrans on Ethanol-induced Ulcer in Albino Rats. An Acad Bras Cienc., 2019; 91(2): e20181044: 1-8.

14. Williamson EM, Okpako DT, Evans FJ, Pharmacological methods in phytotherapy research: Volume 1: Selection, preparation and pharmacological evaluation of plant material. John Wiley \& Sons Ltd, Chichester, UK, 1996.

15. Shay M, Komarov SA, Fels D, Meranze D, Gruenstein $\mathrm{H}$, Siplet $\mathrm{H}$, A simple method for the uniform production of gastric ulceration in the rat. Gastroenterology, 1945;5: 43-61.

16. Zakaria ZA, Balan T, Azemi AK, Omar MH, Mohtarrudin N, Ahmad Z, Abdullah MN, Desa MN, Teh LK, Salleh MZ, Mechanism(s) of action underlying the gastroprotective effect of ethyl acetate fraction obtained from the crude methanolic leaves extract of Muntingia calabura. BMC Complement Altern Med., 2016;16: 78: $1-17$

17. Pradhan D, Biswasroy P, Singh G, Suri KA, Antiulcerogenic activity of Ethanolic Extract of Cucumis sativus L. against NSAID (ASA) induced Gastric Ulcer in Wistar albino rats. Int J Herb Med., 2013; 1(3): 115-119.

18. Ozbakiş Dengiz G, Gürsan N, Effects of Momordica charantia L. (Cucurbitaceae) on indomethacin-induced ulcer model in rats. Turk J Gastroenterol., 2005; 16(2): 85-88.

19. Desai JK, Goyal RK, Parmar NS, Characterization of dopamine receptor subtypes involved in experimentally induced gastric and duodenal ulcers in rats. J Pharm Pharmacol., 1999; 51(2): 187-192.

20. Payyappallimana $U$, Role of traditional medicine in primary health care: an overview of perspectives and challenging. Yokohama J Soc Sci., 2010; 14(6): 57-77.

21. Li JW, Vederas JC, Drug discovery and natural products: end of era or an endless frontier? Biomed Khim., 2011; 57(2): 148-160, (available in Russian).

22. Verma S, Singh SP, Current and future status of herbal medicines. Vet World, 2008; 1(11): 347-350.

23. Hollander D, Tarnawski A, Krause WJ, Gergely H, Protective effect of sucralfate against alcohol-induced gastric mucosal injury in the rat. Macroscopic, histologic, ultrastructural, and functional time sequence analysis. Gastroenterology, 1985; 88(1 Pt2): 366-374.

24. Arab HH, Salama SA, Omar HA, Arafa el-SA, Maghrabi IA, Diosmin protects against ethanol-induced gastric injury in rats: novel anti-ulcer actions. PLoS One, 2015; 10(3): e0122417: 1-21.

25. Bussmann RW, Glenn A, Fighting pain: Traditional Peruvian remedies for the treatment of Asthma, Rheumatism, Arthritis and sore bones. Fighting pain: Traditional Peruvian remedies for the treatment of Asthma, Rheumatism. Arthritis Sore Bones, 2011; 10(3): 397-412.

26. Pandey G, Khatoon S, Evaluation of phytochemical profile and antioxidant activity of Equisetum hyemale 
FARMACIA, 2021, Vol. 69, 2

L. World Journal of Pharmaceutical Research, 2017; 6(3): 723-737.

27. Rainsford KD, The effects of 5-lipoxygenase inhibitors and leukotriene antagonists on the development of gastric lesions induced by nonsteroidal antiinflammatory drugs in mice. Agents Actions, 1987; 21(3-4): 316-319.

28. Sasaki N, Matsuno K, Okabe S, Selective action of a CCK-B/gastrin receptor antagonist, S-0509, on pentagastrin-, peptone meal- and beer-stimulated gastric acid secretion in dogs. Aliment Pharmacol Ther., 2000; 14(4) :479-488.
29. Ayada K, Oguri S, Yamaguchi K, Kumagai K, Endo $\mathrm{Y}$, Elevation of histidine decarboxylase activity in the stomach of mice by ulcerogenic drugs. Eur $J$ Pharmacol., 2003; 460(1): 63-69.

30. Bruggeman TM, Wood JG, Davenport HW, Local control of blood flow in the dog's stomach: vasodilatation caused by acid back-diffusion following topical application of salicylic acid. Gastroenterology, 1979; 77(4 Pt1): 736-44.

31. Venables CW, Mucus, pepsin, and peptic ulcer. Gut, 1986; 27(3): 233-238. 